УДК 378.1:004.41

Мельников Олександр Юрійович

кандидат технічних наук, доцент, доцент кафедри інтелектуальних систем прийняття рішень

Донбаська державна машинобудівна академія, м. Краматорськ, Україна

ORCID ID 0000-0003-2701-8051

alexandr@melnikov.in.ua

\title{
АВТОМАТИЗОВАНА ІНФОРМАЦЙНА СИСТЕМА ОПРАЦЮВАННЯ СТАНДАРТІВ ТА РОЗРОБЛЕННЯ ОСВІТНІХ ПРОГРАМ ДЛЯ ЗАКЛАДІВ ВИЩОЇ ОСВІТИ
}

\begin{abstract}
Анотація. У статті розглянуто пов'язані зі стандартами вищої освіти й освітньопрофесійних програм основні поняття компетентності, програмні результати навчання. Проведено аналіз і зроблено висновок, що до цього часу немає комп'ютерної (програмної) системи, що дозволяє комплексно вирішувати завдання автоматизації процесу створення освітніх програм на основі освітніх стандартів та обробки результатів навчання студентів 3 урахуванням компетентнісного підходу. Сформульовано завдання створення інформаційної системи, що дозволяла б працювати зі списком компетентностей, які потрібно сформувати, та програмних результатів навчання з урахуванням виконання студентами навчального плану. Наведено об'єктно орієнтовану модель проєктованої комп'ютерної системи мовою візуального моделювання UML у вигляді діаграми варіантів використання й діаграми класів. Обгрунтовано вибір формату вихідних даних, що дозволяв би вносити зміни в дані без використання додатку, а також не висувати додаткові вимоги до установки програмного забезпечення. Наведено опис комп'ютерної реалізації інформаційної системи, здійсненої в середовищі візуального програмування Object-Pascal, і приклад роботи системи на підставі реальних даних - стандарту підготовки бакалавра за спеціальністю 124 «Системний аналіз» та освітньо-професійної програми «Інтелектуальні системи прийняття рішень». Показано, що робота зі стандартом вищої освіти дозволяє переглянути загальні компетентності, спеціальні (фахові) компетентності та програмні результати навчання у вигляді матриці відповідності. Робота 3 освітньою програмою крім цього дозволяє створювати та коректувати матрицю відповідності компетентностей компонентам і матрицю забезпечення програмних результатів навчання компонентами. Робота 3 навчальним планом припускає встановлення відповідності кожної дисципліни програмним результатам за підсумками їі вивчення, розрахунок обсягу кредитів ECTS на кожну компетентність або програмний результат навчання, а також аналіз успішності студента або цілої групи в термінах компетентностей або програмних результатів навчання, які вони засвоїли.
\end{abstract}

Ключові слова: стандарт вищої освіти; освітньо-професійна програма; компетентності; програмні результати навчання; навчальні дисципліни; інформаційна система; Unified Modeling Language; Object-Pascal.

\section{1. ВСТУП}

Постановка проблеми. Стандарт вищої освіти (CBO) - це сукупність норм, які встановлюють основну мету й задачі освіти, вимоги до змісту освіти, рівень підготовки фахівців, визначають спосіб діагностики якості вищої освіти. Кожен заклад вищої освіти на основі затвердженого стандарту для кожної спеціальності розробляє освітню (освітньо-професійну або освітньо-наукову) програму, яка може затверджуватись або змінюватись щорічно.

Створення освітніх програм на основі існуючих стандартів, їх порівняння та вдосконалення є, звісно, творчим процесом, але необхідність постійного оновлення матеріалів та проведення оцінки якості вимагає залучення інформаційних систем та технологій. 
Аналіз останніх досліджень і публікацій. До 2016 року стандарт вищої освіти [1] складався 3 двох частин - «Освітньо-кваліфікаційні характеристики» (ОКХ) та «Освітньо-професійної програми» (ОПП). Освітньо-кваліфікаційна характеристика випускника вищого навчального закладу (ОКХ) була галузевим нормативним документом, у якому узагальнювався зміст вищої освіти, тобто відображались цілі вищої освіти та професійної підготовки, визначалось місце фахівця в структурі галузей економіки держави і вимоги до його компетентності, інших соціально важливих властивостей та якостей. Одним з основних понять у стандарті [1] була компетенція -, яка «включає знання й розуміння (теоретичне знання академічної області, здатність знати й розуміти), знання як діяти (практичне й оперативне застосування знань до конкретних ситуацій), знання як бути (цінності як невід'ємна частина способу сприйняття й життя 3 іншими в соціальному контексті)». Визначались п'ять видів компетенцій: соціально-особистісні, загальнонаукові, інструментальні, загальнопрофесійні, спеціалізовано-професійні [1]. Уміння розподілялись на предметнопрактичні, предметно-розумові, знаково-практичні та знаково-розумові, типові задачі діяльності - на професійні, соціально-виробничі та соціально-побутові. Освітньопрофесійна програма була галузевим нормативним документом, у якому визначались нормативний термін та зміст навчання, нормативні форми державної атестації, встановлюлись вимоги до змісту, обсягу й рівня освіти та професійної підготовки фахівця відповідного освітньо-кваліфікаційного рівня певного напрямку. Також освітньо-професійна програма містила рекомендований перелік навчальних дисциплін і перелік компетенцій $з$ освітньо-кваліфікаційної характеристики, що формуються в кожній дисципліні.

Згідно з прийнятими Міністерством освіти і науки України новими правилами [2] відтепер «Стандарт вищої освіти» визначає такі вимоги:

1) обсяг кредитів ЄКТС, необхідний для здобуття відповідного ступеня вищої освіти;

2) перелік компетентностей випускника;

3) нормативний зміст підготовки здобувачів вищої освіти, сформульований у термінах результатів навчання;

4) форми атестації здобувачів вищої освіти;

5) вимоги до наявності системи внутрішнього забезпечення якості вищої освіти;

6) вимоги до професійних стандартів (у разі їх наявності).

Тобто тепер він не містить розподілення на освітньо-професійну програму та освітньо-кваліфікаційну характеристику, має тільки два види компетентностей (загальні та спеціальні/фахові), нормативний зміст у вигляді переліку знань та вмінь, а також два додатки: матрицю відповідності дескрипторів національної рамки кваліфікацій (знання - уміння - комунікація - відповідальність) кожної компетентності; матрицю відповідності програмних результатів навчання (тобто списку знань і вмінь) списку компетентностей [3].

Кожен заклад вищої освіти на основі затвердженого стандарту для кожної спеціальності розробляє освітню (освітньо-професійну або освітньо-наукову) програму, що містить загальні компетентності, спеціальні (фахові) компетентності, програмні результати навчання, освітні компоненти (перелік дисциплін навчального плану), структурно-логічну схему та матриці відповідності компетентностей і програмних результатів навчання (ПРН) компонентам програми (тобто дисциплінам). Програмні результати навчання в освітній програмі повинні забезпечити, як правило, не менше $50 \%$ компетентностей СВО. Число компетентностей і ПРН може бути більшим або рівним своїм аналогам зі СВО. Як правило, освітньо-професійна програма складається у закладі вищої освіти та може затверджуватись або змінюватись щорічно. 
Заклад вищої освіти при розробленні освітніх програм самостійно визначає перелік та зміст компонентів [4], керуючись підпунктом 17 частини першої статті 1 Закону України «Про вищу освіту» [5].

Водночас українські заклади вищої освіти використовують компетентнісний підхід [6], якій рекомендовано європейським проєктом TUNING [7]. Цей підхід пропонує описувати результати навчання мовою компетентностей, якими повинен володіти випускник, тобто результатом $\epsilon$ ступінь готовності випускника продемонструвати відповідні компетентності [6]. Взагалі, проєкт TUNING [7] пропонує перенести акцент освітнього процесу з викладачів, коли на результат значною мірою впливає комбінація сфер інтересів і досвіду професорсько-викладацького персоналу, на студентів, щоб ключові знання, уміння та навички, якими повинен оволодіти студент за час навчання, визначали зміст навчальної програми.

У результаті пошуку єдиних принципів та рекомендацій процесу створення освітніх програм у європейських країнах стало зрозуміло, що автономія європейських університетів не передбачає наявності єдиних стандартів, які б були доступні на інтернет-сайті міністерства освіти [8]-[9]. Кожен університет створює власні програми з урахуванням місцевих, державних та загальноєвропейських потреб. Наприклад, існує «Єдина європейська система електронних компетенцій 16234-1» [10], яка містить довідник по 40 компетенціях, застосовуваним на робочому місці в галузі інформаційних і комунікаційних технологій (IКТ) з використанням спільної мови для компетенцій, навичок, знань і навичок.

В [11] аналізується досвід російських вузів 3 інтеграції професійних і освітніх стандартів при проєктуванні освітніх програм вищої освіти у сфері інформаційнокомунікаційних технологій. Виявлено ряд аспектів поточних версій освітніх стандартів, які представляють проблему для сполучення з професійними стандартами при розробці основних освітніх програм. Представлені методичні рекомендації щодо актуалізації державних освітніх стандартів ВО і відбору професійних стандартів, вироблені провідними російськими вузами в результаті виконання міжнародних і вітчизняних проєктів. Проведено аналіз відповідності узагальнених трудових функцій і їх складових з професійних стандартів загальної і професійних компетенцій за напрямом підготовки «Фундаментальна інформатика та інформаційні технології».

У [12] наводиться аналіз відповідності освітнього процесу вимогам освітніх стандартів на прикладі факультету економіки і менеджменту, але увага приділяється не структурі і змісту навчальних програм, а кадровому забезпеченню освітнього процесу.

У [13] представлено аналіз досвіду модернізації програм бакалаврату 3 використанням методології TUNING. Пояснений алгоритм реформування навчальних планів 3 предметної області інформаційних технологій відповідно до методології TUNING. Проводиться порівняння між існуючими російськими і європейськими стандартами в галузі освіти у сфері IKT, зокрема щодо Європейської системи електронної компетентності, з акцентом на відповідні компетенції, та надаються деякі керівні принципи для підготовки освітніх програм.

Дослідження [14] присвячено питанням застосування компетентнісного підходу у вищій школі при формуванні вимог державних освітніх стандартів до якості освіти. Для кількісної характеристики якості навчання визначені групи критеріїв (показників) та їх вагові коефіцієнти. Запропонована індикативна методика оцінки якості освіти, яка передбачає опитування експертів-викладачів та експертів-роботодавців.

Але всі наведені дослідження проводились фактично без використання інформаційних систем, їх результати не можуть бути легко спроєктовані на інші галузі. Більшість проєктів автоматизованих систем (наприклад, [15]) спрямовані на аналіз 
якості навчання студентів і відрізняються методикою обробки зібраного матеріалу, без аналізу змісту освітніх програм.

Аналіз доступних джерел інформації показав, що на цей час не існує комп'ютерної системи, яка дозволяє комплексно вирішувати задачі, пов'язані 3 обробкою освітніх стандартів і освітніх програм. Одна 3 систем [16]-[18] дозволяє вносити, зберігати й обробляти більшу частину інформації. Вона передбачає можливість роботи користувачів трьох рівнів: адміністратор системи (admin) змінює основні дані, головний користувач (main user) формує й коректує ОКХ i ОПП, звичайний користувач (user) одержує інформацію в потрібному вигляді (кожен з них має доступ до всієї інформації, закривається тільки можливість ії змінювання). Система працює з базами даних «Класи компетенцій», «Виробничі функції», «Види типових задач діяльності», «Класи задач діяльності», «Види умінь», «Рівні сформованості уміння». У режимі роботи з ОКХ створюються таблиці «Компетенції», «Типові задачі діяльності», «Уміння для забезпечення типових задачі діяльності», «Уміння для забезпечення обраної компетенції». У режимі роботи з ОПП опрацьовуються таблиці «Назви циклів дисциплін», «Назви дисциплін», «Назви блоків змістових модулів», «Назви змістових модулів», «Перелік змістових модулів для забезпечення кожного уміння», «Перелік блоків змістових модулів для забезпечення державної атестації».

Ця система не має чіткого розподілу даних на стандартні (тобто «Стандарт вищої освіти») та створені в закладі вищої освіти («Освітня програма»), не дозволяє проводити оцінку відповідності ОПП стандарту та взагалі базується на застарілому переліку компетенцій.

Мета статті. Комплексно вирішити завдання автоматизації процесу створення освітніх програм на основі освітніх стандартів та обробки результатів навчання студентів з урахуванням компетентнісного підходу шляхом створення інформаційної системи, що дозволяла б працювати зі списком компетентностей, які формуються. та програмних результатів навчання з урахуванням виконання студентами навчального плану. Система повинна надавати можливість імпортувати всі наявні дані, вносити зміни в будь-який розділ і водночас працювати з даними XLS-формату:

- забезпечувати подання наявної інформації в одному застосунку (для зручності користування);

- установлювати посилання кожного пункту ОПП на СВО (яка компетентність ОПП забезпечує компетентність СВО тощо);

- працювати зі СВО - вивчати матрицю відповідності програмних результатів навчання компетентностям;

- працювати з ОПП - створювати матрицю відповідності програмних результатів навчання компетентностям, а також визначати, які програмні результати навчання відповідають кожній дисципліні;

- працювати з ОПП -отримувати список компетентностей, які одержує студент 3 кожної дисципліни;

- проводити простий аналіз відповідності ОПП СВО та наявності незабезпечених компетентностей;

- проводити розрахунок, наскільки серйозно забезпечені ті або інші ПРН і компетентності, проаналізувавши освітні компоненти (кредити);

- проводити розрахунок успішності студентів у термінах компетентностей i програмних результатів навчання.

Використання такої системи полегшить роботу 3 навчально-методичними документами на кафедрах при підготовці матеріалів до ліцензування й акредитації. 


\section{2. РЕЗУЛЬТАТИ ДОСЛІДЖЕННЯ}

\section{1. Інформаційна модель системи, яка просктується}

Інформаційна модель системи створювалась уніфікованою мовою моделювання UML (Unified Modeling Language). Візуальне моделювання за допомогою UML $\epsilon$ поетапним спуском від найбільш загальної концептуальної моделі системи до логічної, а потім і до фізичної моделі, коли модель являє собою сукупність так званих діаграм [19]-[20]. Можливості системи представлені на діаграмі варіантів використання (use case diagram, діаграма прецедентів), що відображає концептуальну модель системи (рис. 1).

Передбачається один користувач системи (викладач або інший співробітник). Йому доступні основні прецеденти «Робота 3 навчальним планом», «Робота зі стандартом вищої освіти», «Робота з освітньою програмою», «Проведення розрахунку вагомості компонентів ОПП», «Робота 3 файлом даних» та «Налаштування середовища».

«Робота з навчальним планом» передбачає обов'язково (відношення «include») «Відображення програмних результатів навчання» та не обов'язково (відношення «extend») «Внесення змін до плану», «Внесення змін до переліку програмних результатів навчання 3 обраної дисципліни», «Робота 3 показниками успішності студентів», «Відображення діаграми вагомостей».

«Робота зі стандартом вищої освіти» передбачає обов'язково (відношення «include») «Перегляд та модифікація фахових компетентностей стандарту вищої освіти», «Перегляд та модифікація загальних компетентностей стандарту вищої освіти», «Перегляд та модифікація програмних результатів навчання стандарту вищої освіти» та не обов'язково (відношення «еxtend») «Встановлення відповідності програмних результатів навчання компетентностям стандарту вищої освіти».

«Робота $з$ освітньою програмою» передбачає обов'язково (відношення «include») «Перегляд та модифікація загальних компетентностей освітньо-професійної програми», «Встановлення відповідності загальних компетентностей освітньо-професійної програми загальних компетентностей стандарту вищої освіти», «Перегляд та модифікація фахових компетентностей ОПП», «Встановлення відповідності фахових компетенцій освітньо-професійної програми фаховим компетентностям стандарту вищої освіти», «Перегляд та модифікація програмних результатів навчання освітньопрофесійної програми», «Встановлення відповідності програмних результатів навчання освітньо-професійної програми програмних результатів навчання стандарту вищої освіти», «Створення матриць відповідностей» (матриця "компетентності-компоненти", матриця "ПРН-компоненти") та не обов'язково (відношення «еxtend») «Додавання нової загальної компетентності», «Додавання нової фахової компетентності», «Додавання нового програмного результату навчання», «Встановлення відповідності програмних результатів навчання компетентностям освітньо-професійної програми», «Проведення розрахунку якості освітньо-професійної програми».

Структура системи в термінах об'єктно орієнтованого проєктування показана на діаграмі класів (рис. 2). Наведена структура не є занадто складною: користувач асоціативно пов'язаний з керуючим класом («Головна програма»), що містить у собі (відношення агрегації) класи для роботи зі стандартом вищої освіти, освітньопрофесійною програмою і навчальним планом, а також класи - файли даних. 


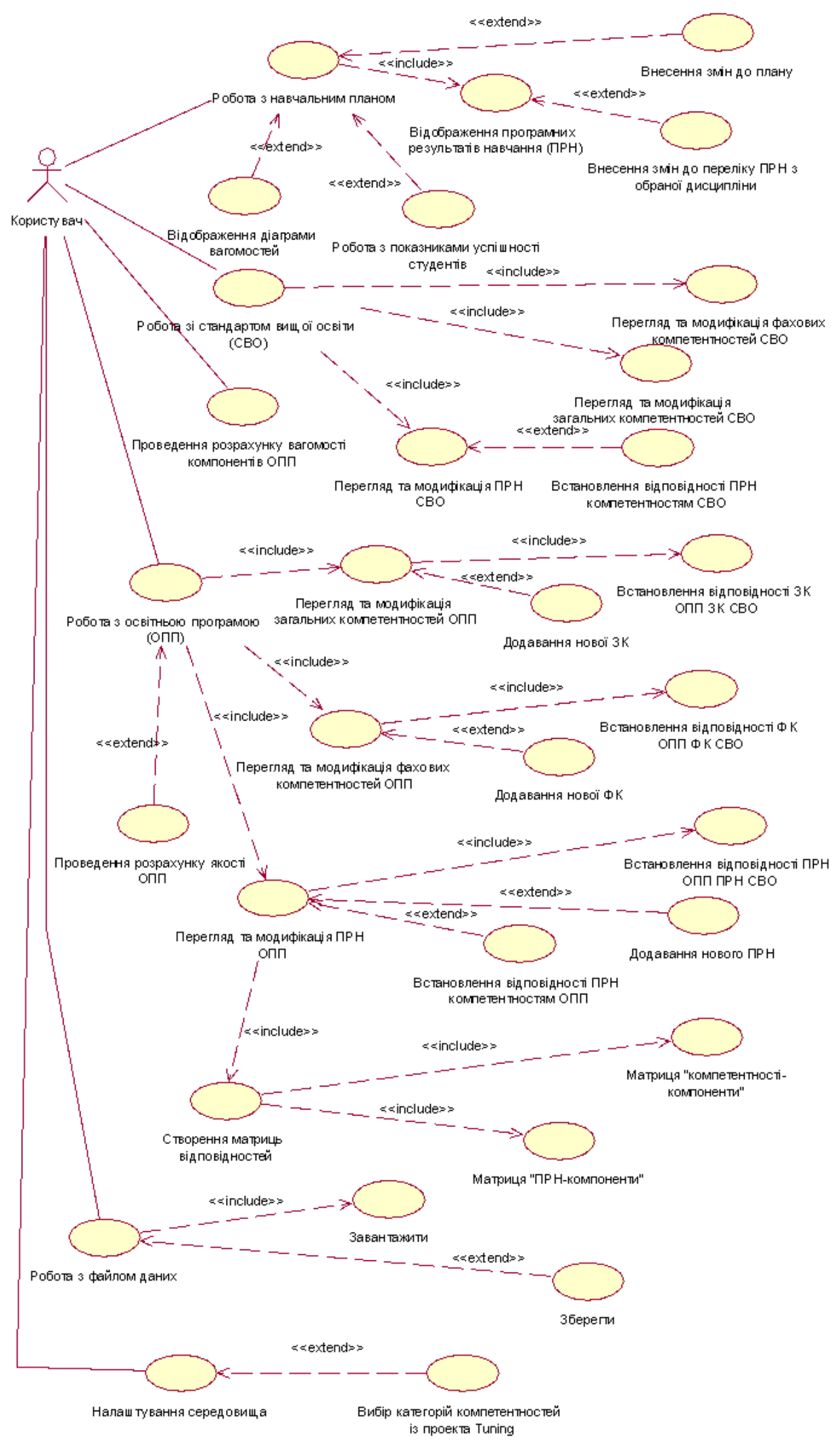

Рис. 1. Діаграма варіантів використання 


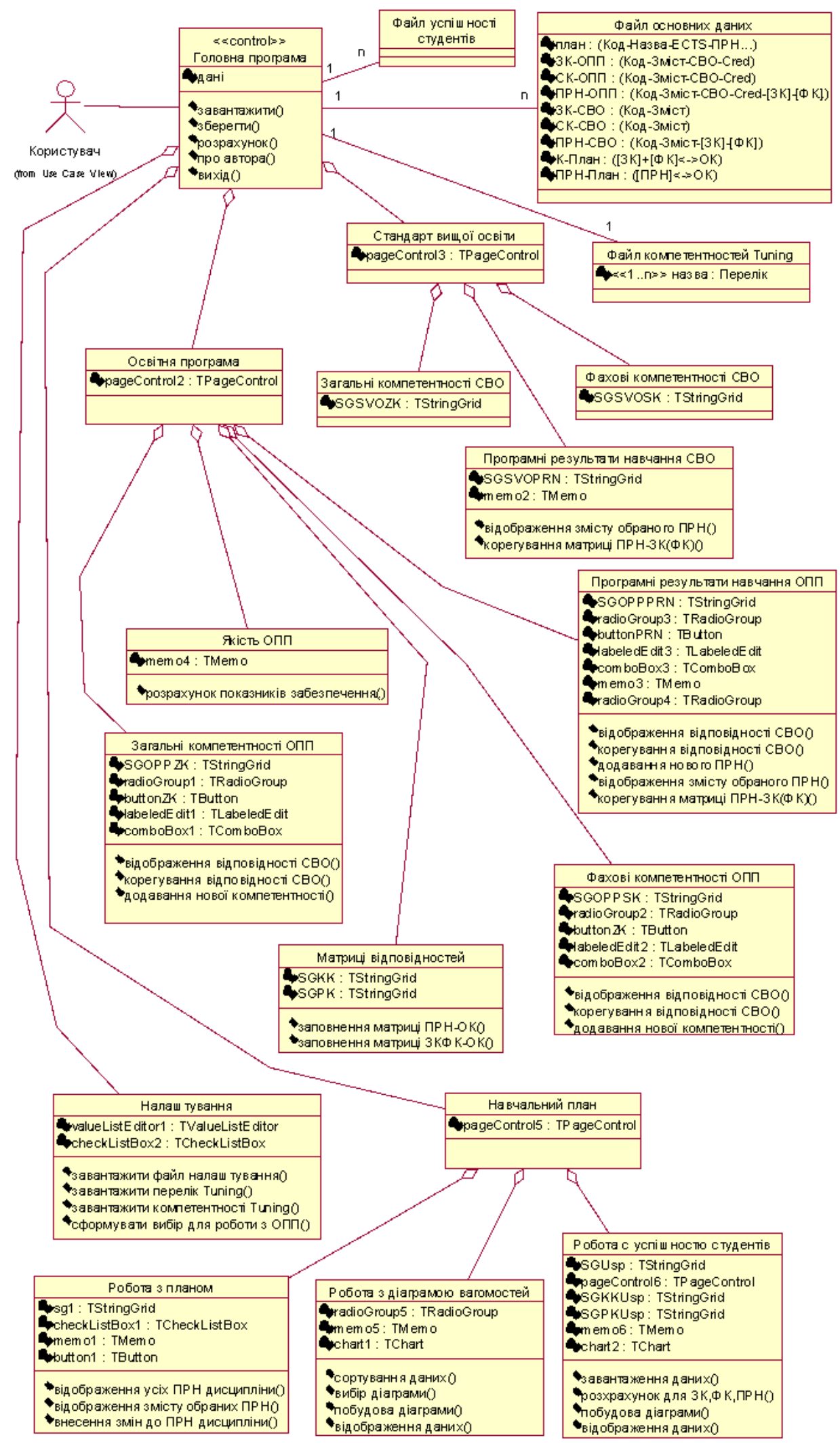

Рис. 2. Діаграма класів 
Як формат вихідних даних обраний XLS. Це дозволяє вносити будь-які зміни в дані без використання системи, а також знімає вимоги встановлення додаткового програмного забезпечення. Один файл - одна спеціальність (освітня програма). Кожен лист несе своє функціональне навантаження (назва неважлива, послідовність обов'язкова):

- План - перелік дисциплін навчального плану (код, назва, обсяг у кредитах ECTS);

- ЗК-ОПП - перелік загальних компетентностей в освітньо-професійній програмі (код, зміст, відповідність стандарту, розрахований обсяг у кредитах ECTS);

- СК-ОПП - перелік спеціальних компетентностей в освітньо-професійній програмі (код, зміст, відповідність стандарту, розрахований обсяг у кредитах ECTS);

- ПРН-ОПП - перелік програмних результатів навчання в освітньо-професійній програмі (код, зміст, відповідність стандарту, розрахований обсяг у кредитах ECTS, відповідність компетентностям ОПП);

- ЗК-СВО - перелік загальних компетентностей у стандарті вищої освіти (код, зміст);

- СК-СВО - перелік спеціальних компетентностей у стандарті вищої освіти (код, зміст);

- ПРН-СВО - перелік програмних результатів навчання у стандарті вищої освіти (код, зміст, відповідність компетентностям стандарту вищої освіти);

- К-План - відповідність компетентностей освітньо-професійної програми іiі компонентам (дисциплінам навчального плану);

- ПРН-План - відповідність програмних результатів навчання освітньопрофесійної програми ії компонентам (дисциплінам навчального плану).

Повинні завантажуватися тільки перші сім аркушів; останні два - створюватися системою і потім зберігатися у файлі по запиту користувача.

Як приклад використано стандарт підготовки бакалавра за спеціальністю 124 «Системний аналіз» та освітньо-професійну програму «Інтелектуальні системи прийняття рішень».

\section{2. Програмна реалізація інформаційної системи для роботи 3 освітніми програмами та стандартами вищої освіти}

Розроблена інформаційна модель програмної системи для роботи 3 освітніми програмами та стандартами вищої освіти була реалізована в середовищі Object Pascal [21]-[22].

Форма додатка містить чотири основні вкладки: «Навчальний план», «Освітня програма», «Стандарт вищої освіти» й «Налаштування».

Робота зі стандартом вищої освіти (рис. 3-5) дозволяє переглянути загальні компетентності, спеціальні компетентності та програмні результати навчання у вигляді матриці відповідності [3]. Користувачу надано можливість вносити в текст зміни, але передбачається, що стандарт затверджений і незмінний. 


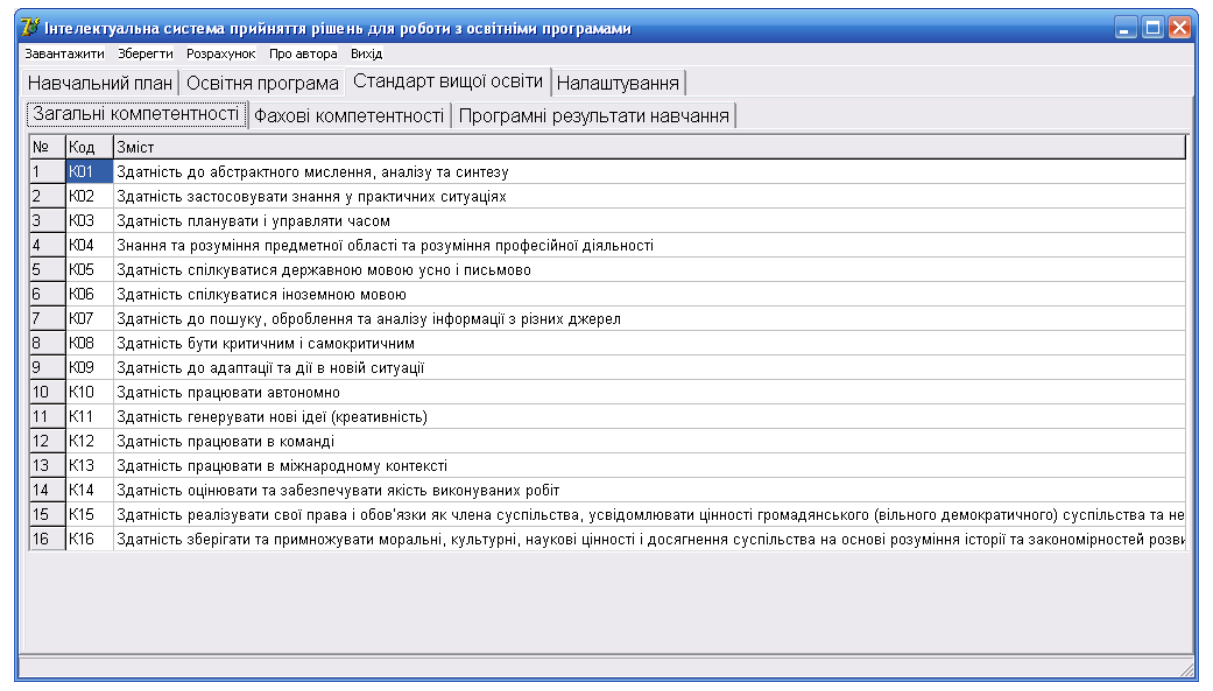

Pис. 3. Робота із СВО: загальні компетентності

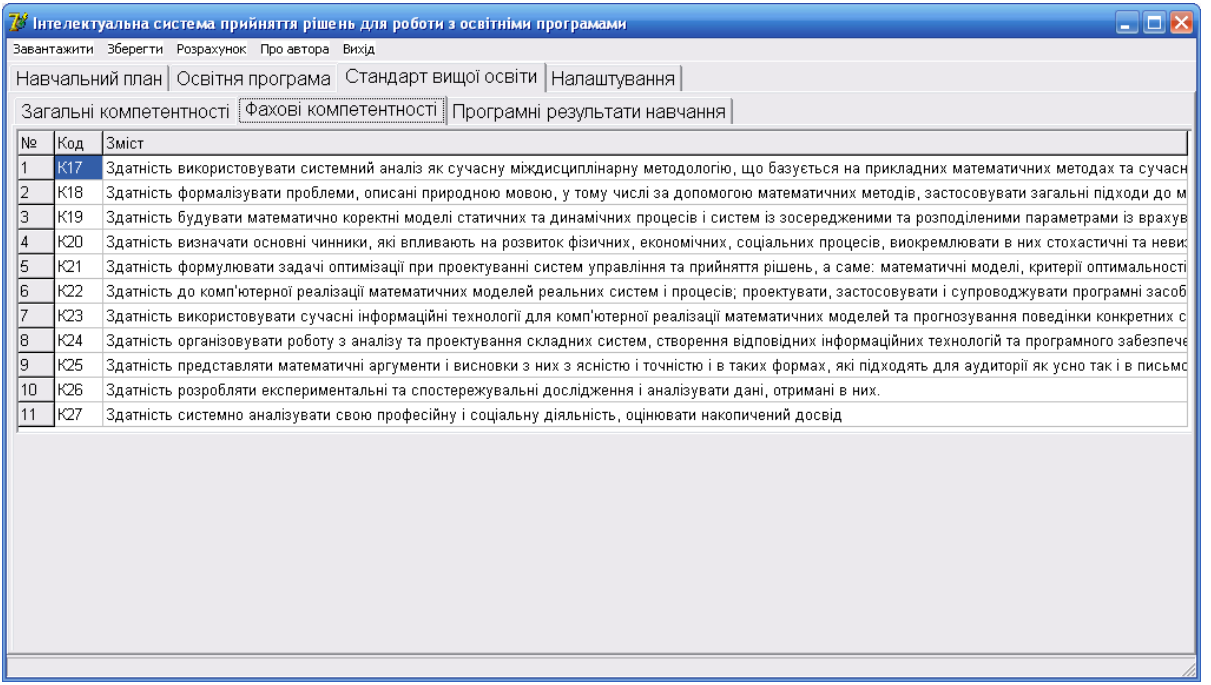

Puc. 4. Робота із CВО: фахові компетентності

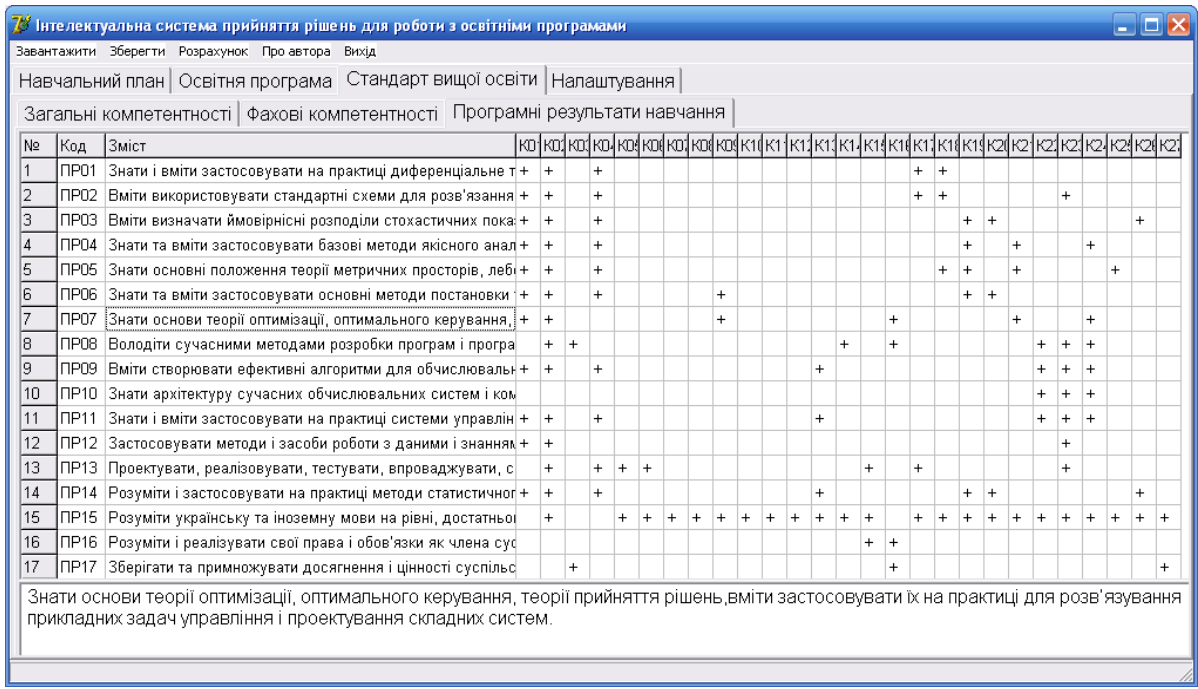

Рис. 5. Робота із СВО: програмні результати навчання 


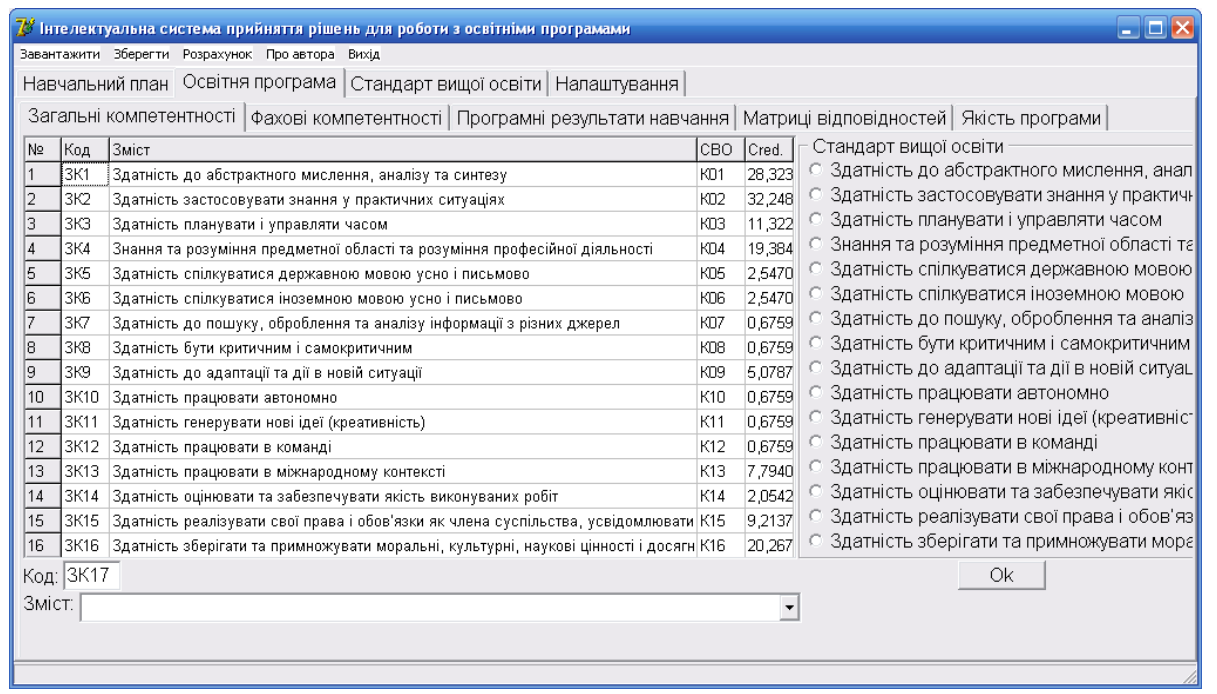

Рис. 6. Робота з ОПП: загальні компетентності

Робота 3 освітньою програмою (рис. 6-11) також дозволяє переглянути загальні компетентності, спеціальні компетентності та програмні результати навчання, у тому числі у вигляді матриці відповідності. Користувач може вносити до тексту зміни, встановлювати відповідність кожного пункту освітньої програми пункту стандарту вищої освіти (якщо така відповідність передбачається), а також додавати нові дані (нові рядки). Новий код розраховується автоматично, але користувач може його змінити. Новий рядок може бути добавлено з допоміжного файлу.

Також приводяться матриця відповідності компетентностей компонентам i матриця забезпечення програмних результатів навчання компонентами, які можна коректувати за допомогою миші та клавіатури. Користувач при роботі з програмними результати навчання має можливість зробити вибір: працювати 3 вікном відповідностями компетентностям або з вікном відповідності стандарту освіти, як у випадках із загальними та фаховими компетентностями.

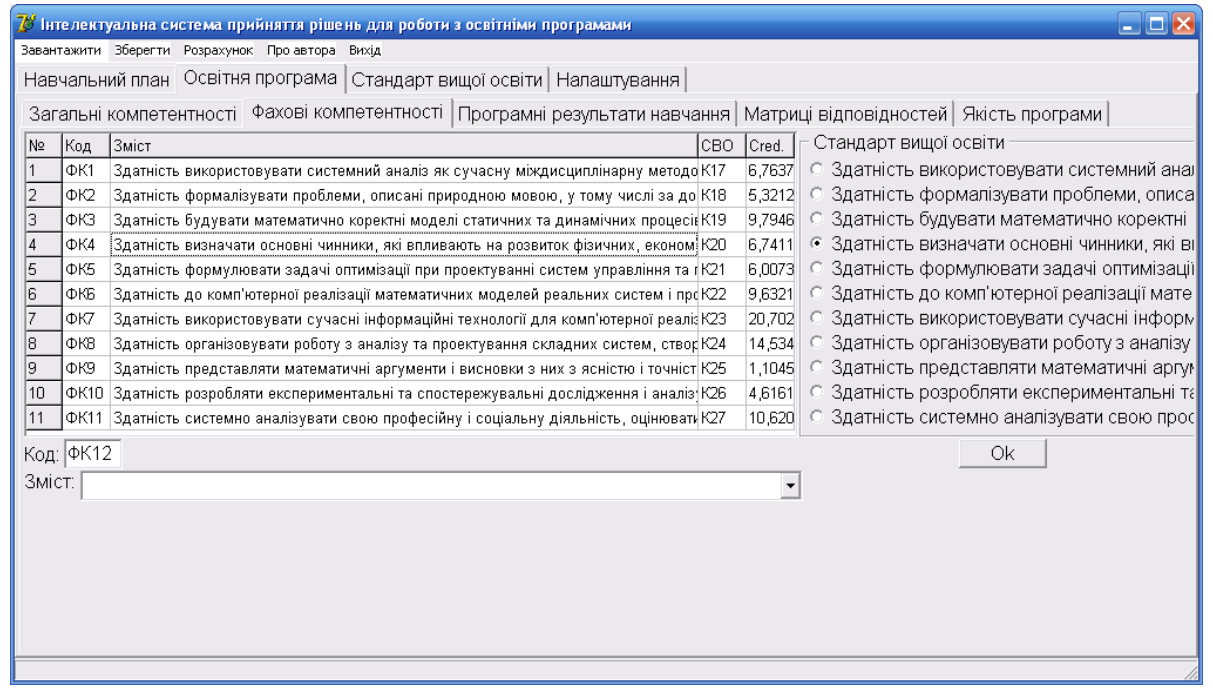

Рис. 7. Робота з ОПП: спеціальні (фахові) компетентності 


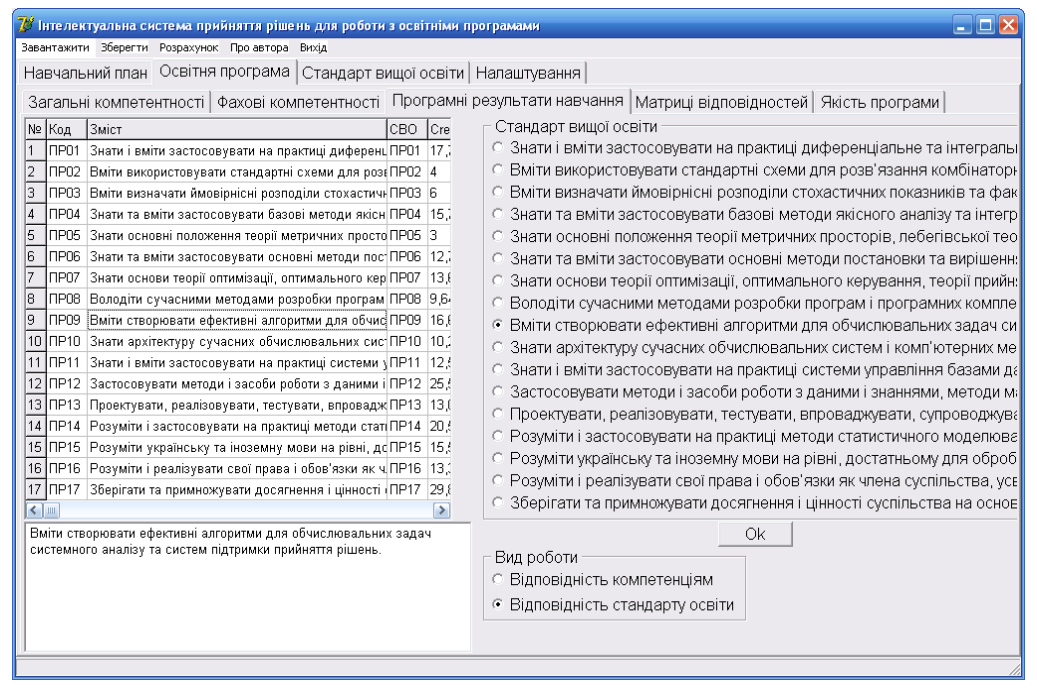

Рис. 8. Робота з ОПП: програмні результати навчання (відповідність СВО)

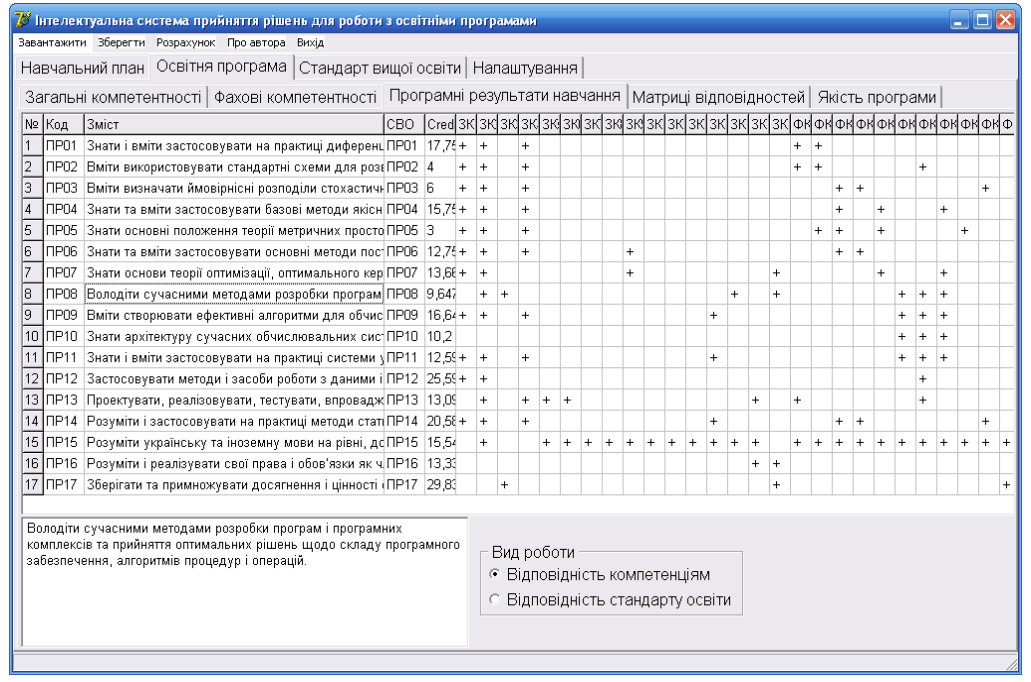

Рис. 9. Робота з ОПП: програмні результати навчання (відповідність компетентностям)

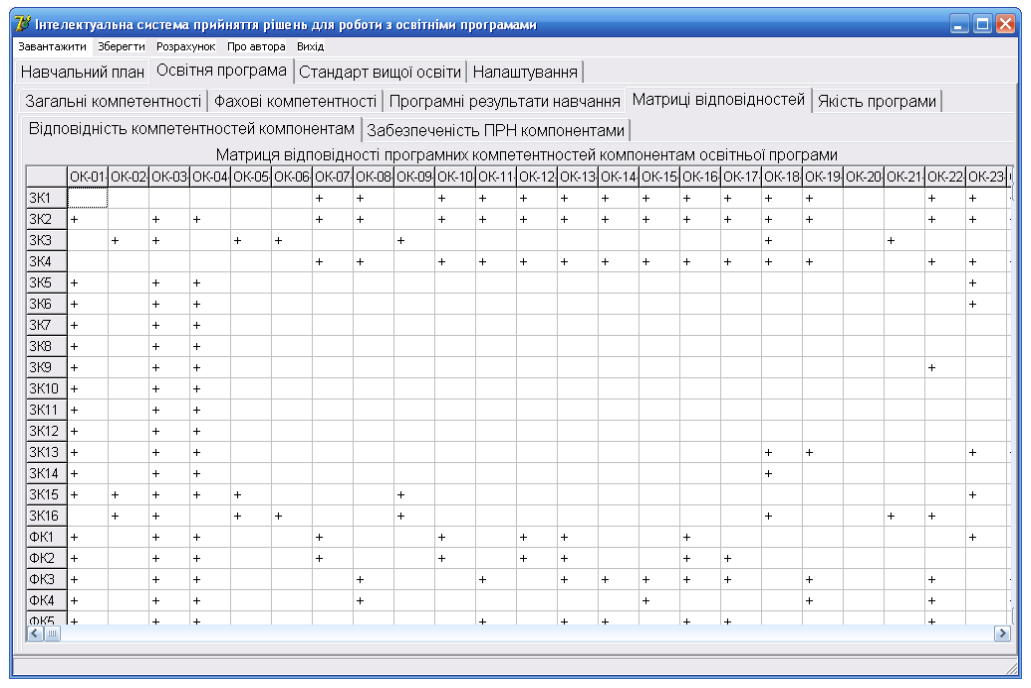

Рис. 10. Робота з ОПП: матриця відповідності компетентностей компонентам 


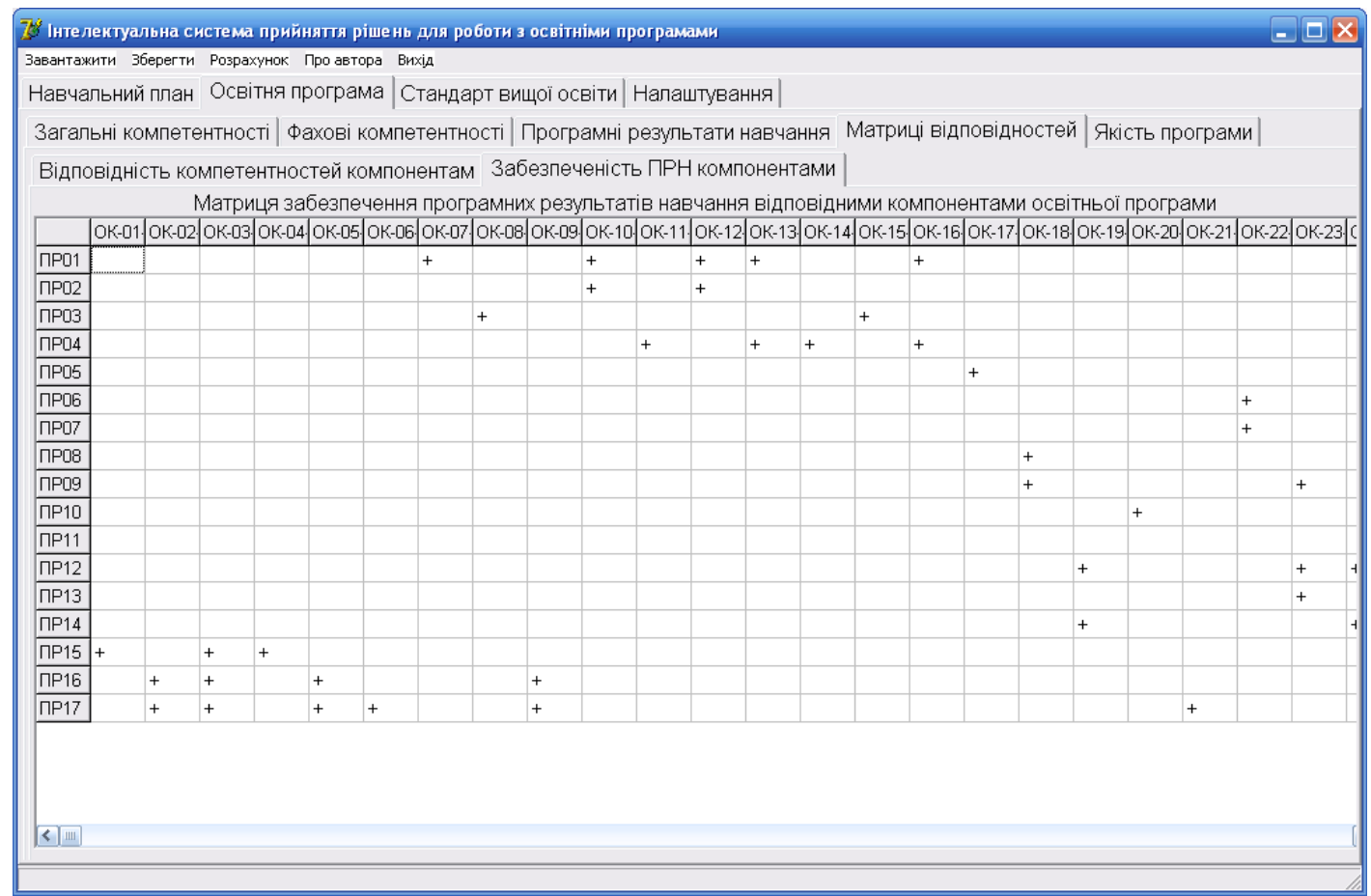

Рис. 11. Робота з ОПП: матричя забезпечення програмних результатів навчання компонентами

Робота 3 навчальним планом припускає встановлення відповідності кожної дисципліни програмним результатам за підсумками ії вивчення (відношення «один до багатьох», до 10 позицій). У правій нижній частині вікна виводяться всі програмні результати навчання з обраної дисципліни. Якщо користувачеві потрібно змінити вибір, він повинен його підтвердити натисканням кнопки «Ok» (рис. 12).

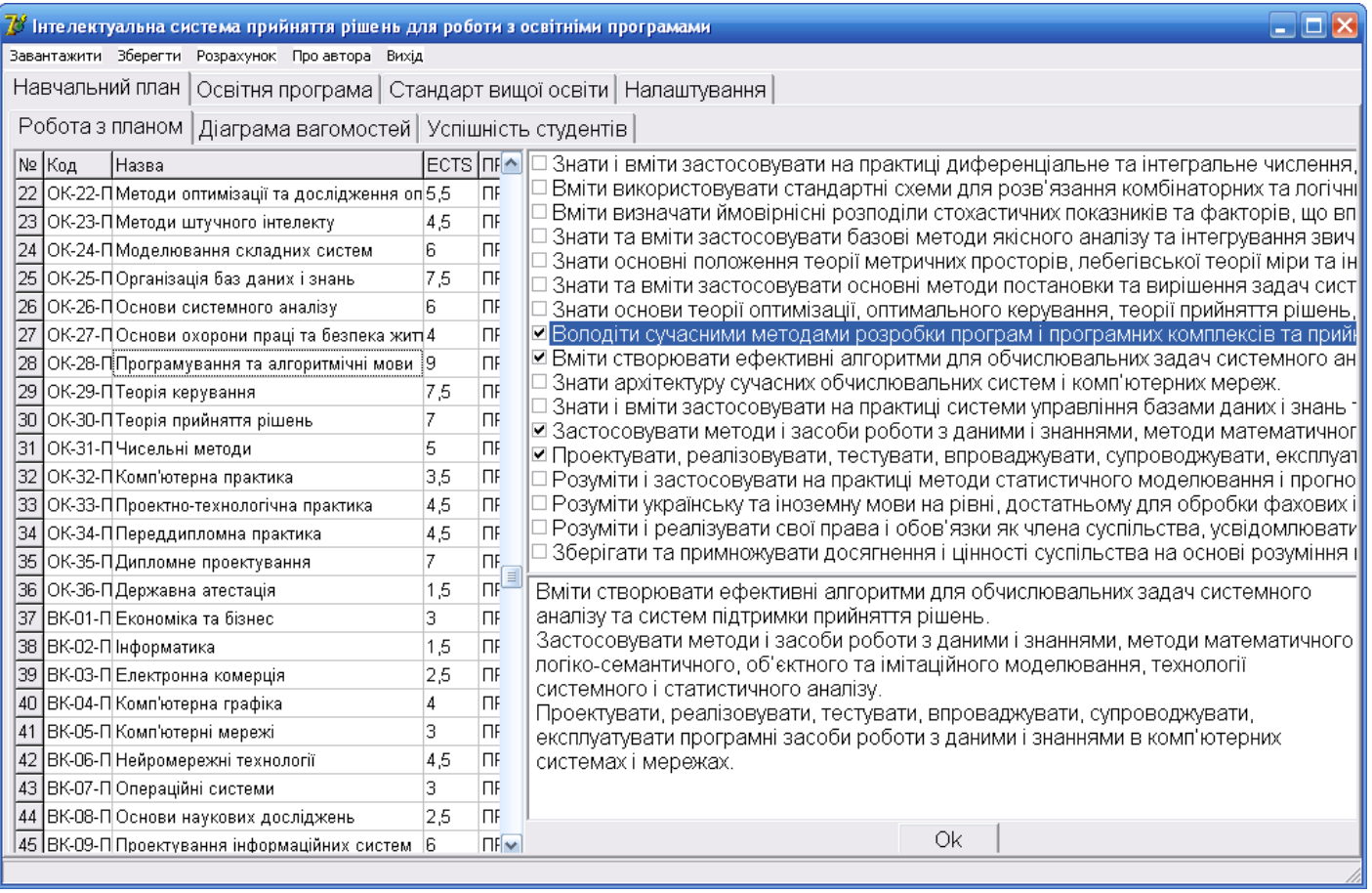

Рис. 12. Робота з навчальним планом 
Особливістю розробленої системи є можливість роботи з вагомостями кожної компетентності або результату навчання. При виборі пункту меню «Розрахунок» система за наявним даними з матриці відповідності заповнює осередки кредитів, яким обсягом кредитів ECTS забезпечується кожна компетентність або програмний результат навчання. Користувач має можливість переглянути вагомості кожної загальної компетентності (рис. 13), фахової компетентності (рис. 14) та програмного результату навчання (рис. 15).

На стовбцях діаграм відображаються значення (показники) вагомостей у кредитах ЄКТС, зліва у текстовому полі - зміст обраної компетентності або програмного результату навчання.

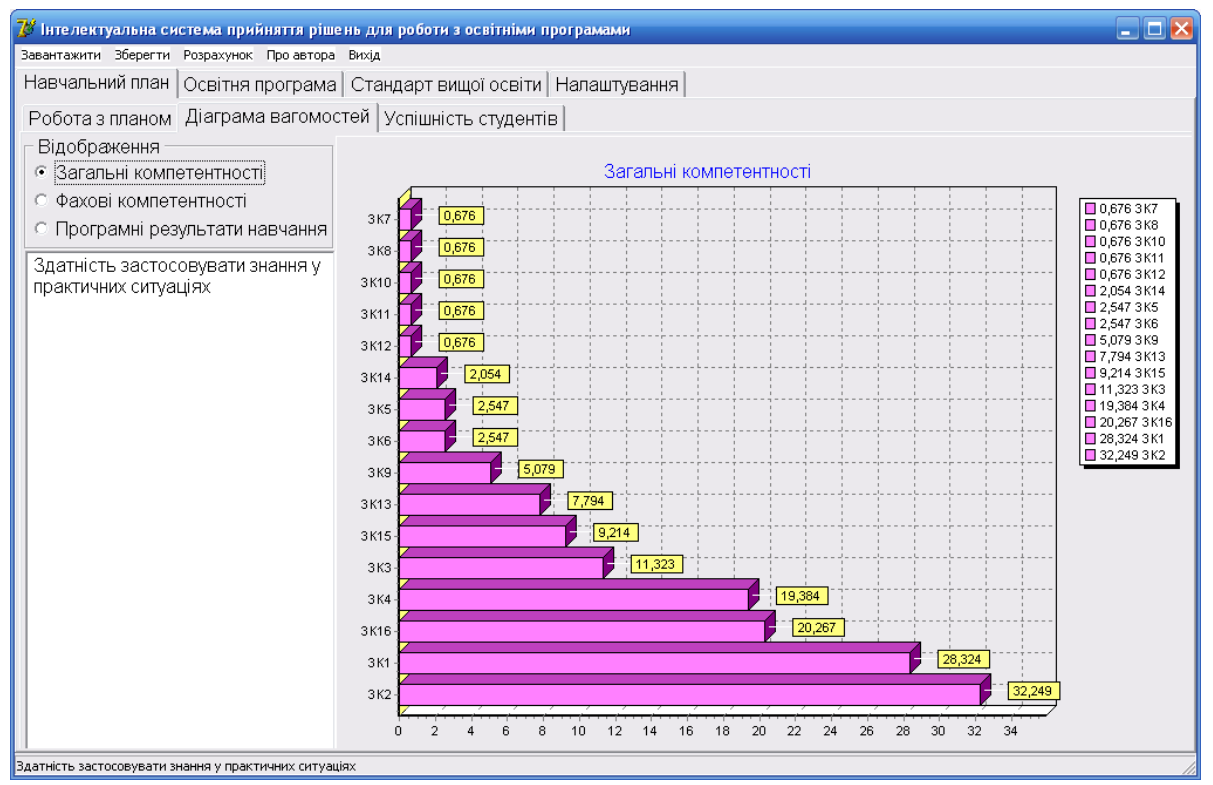

Рис. 13. Робота з вагомостями: загальні компетентності

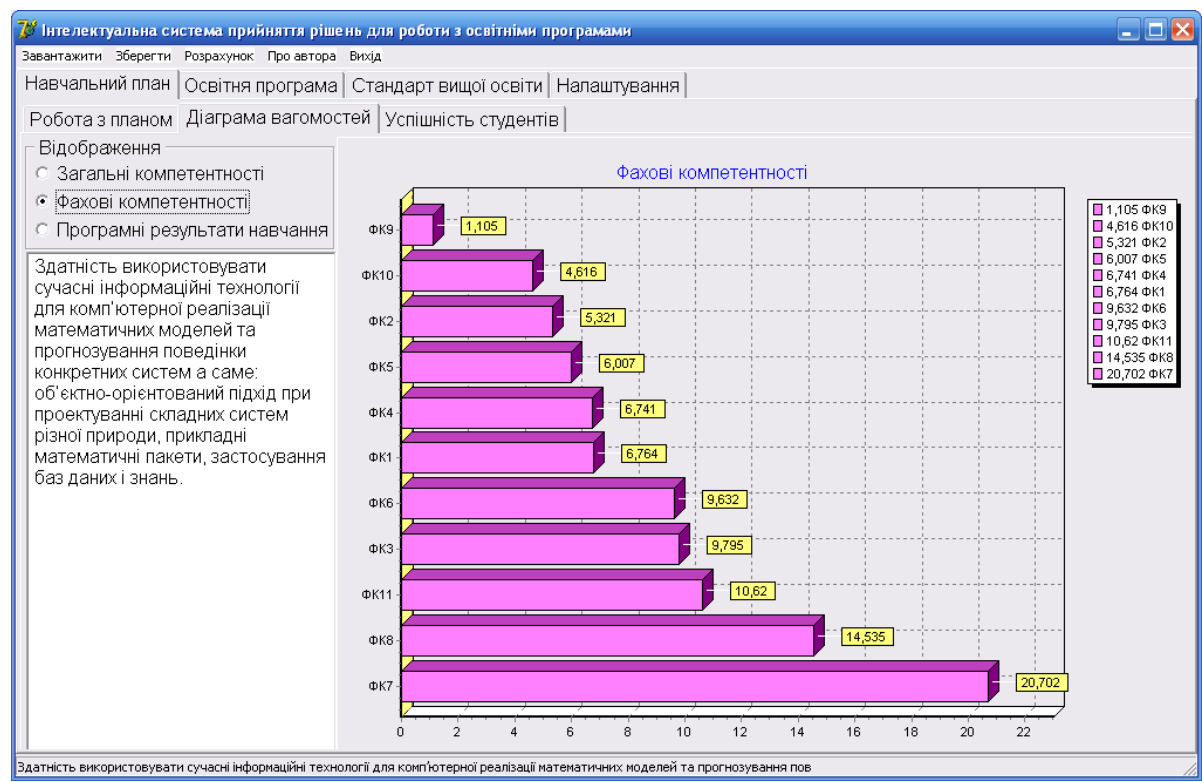

Рис. 14. Робота з вагомостями: фахові компетентності 


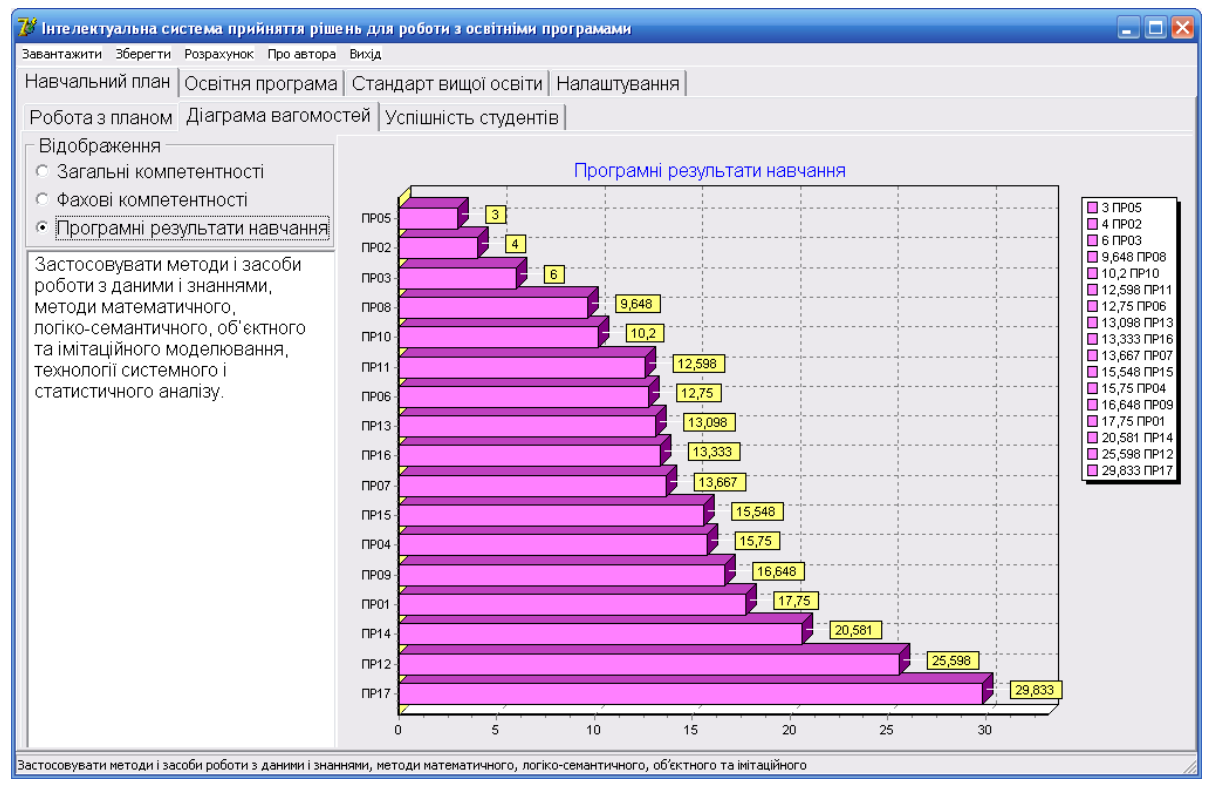

Рис. 15. Робота з вагомостями: програмні результати навчання

Ще одна особливість системи - можливість аналізу успішності студента або цілої групи в термінах компетентностей або програмних результатів навчання, які вони засвоїли. Вхідний файл «Група1.xls» містить оцінки студентів (у стовпцях) з кожної дисципліни навчального плану (у рядках). Якщо студент з якихось причин не вивчав ту або іншу дисципліну, ставиться «нуль», і рядок не буде враховано при розрахунках.

На рис. 16-17 представлені приклади розрахунку успішності студента по компетентностям і програмних результатах навчання відповідно, на рис. 18-19 - те ж саме для усередненого показника студентської групи.

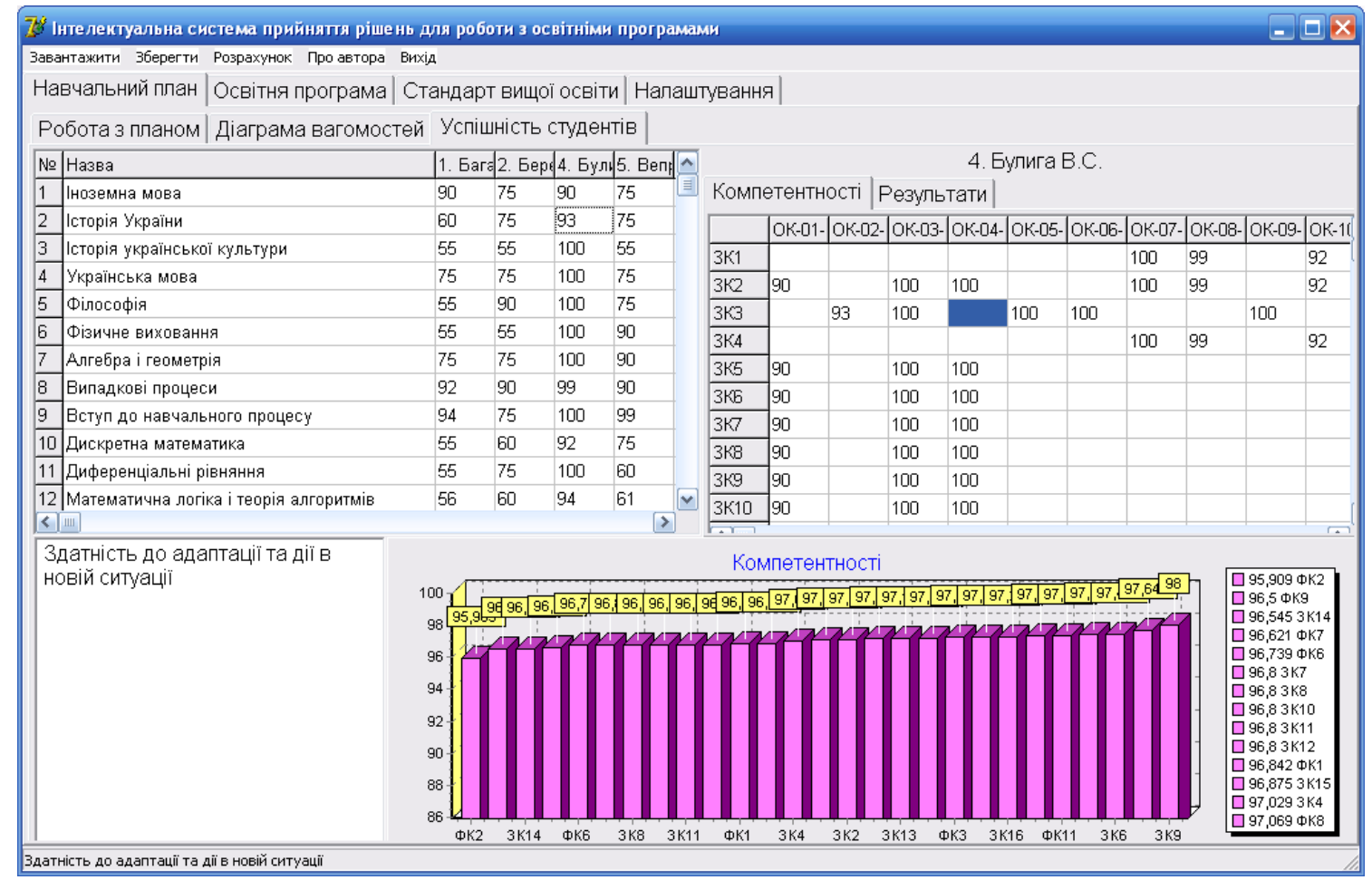

Рис. 16. Робота с успішністю студента по компетентностям 


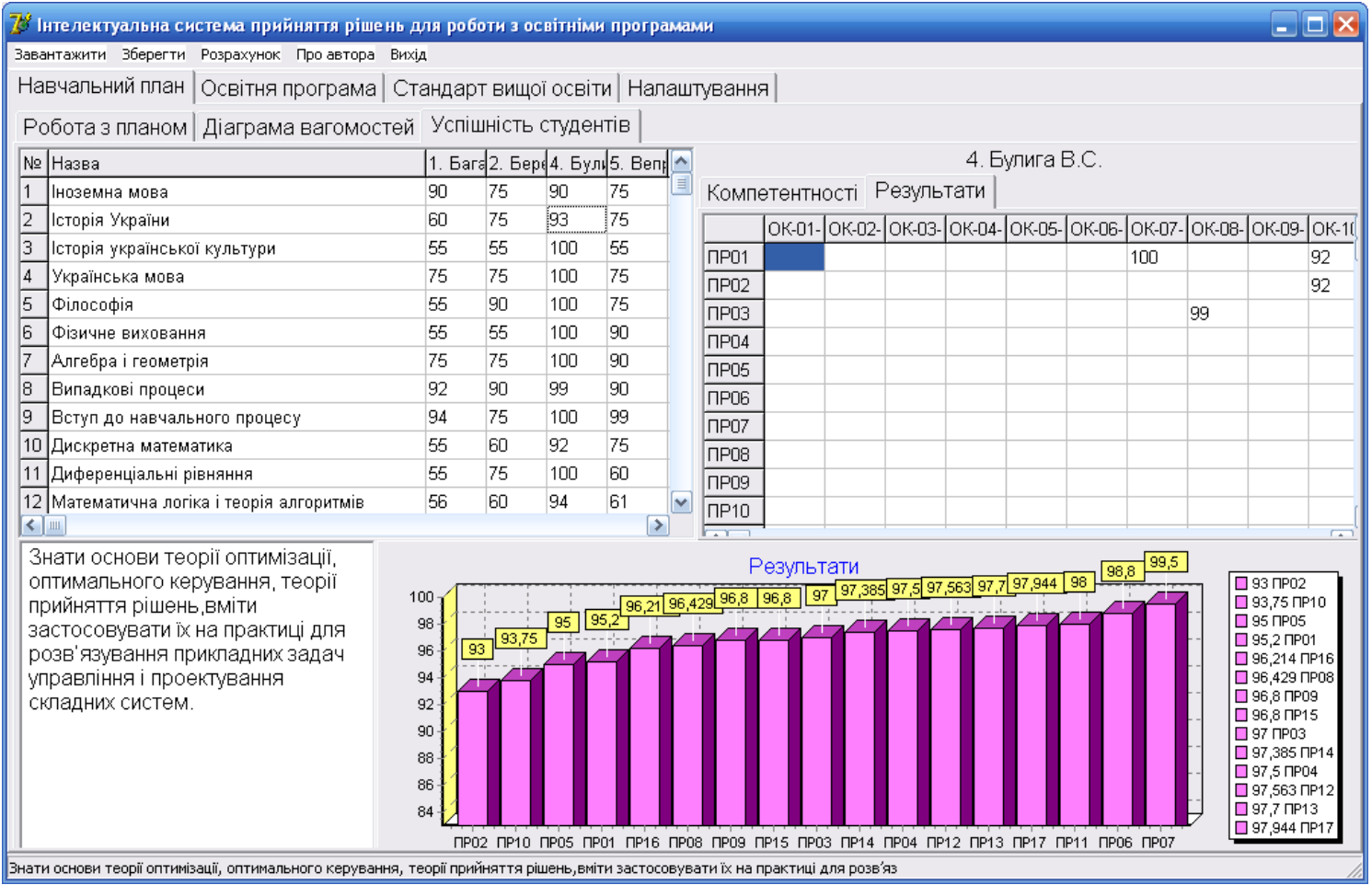

Рис. 17. Робота с успішністю студента по програмним результатам навчання

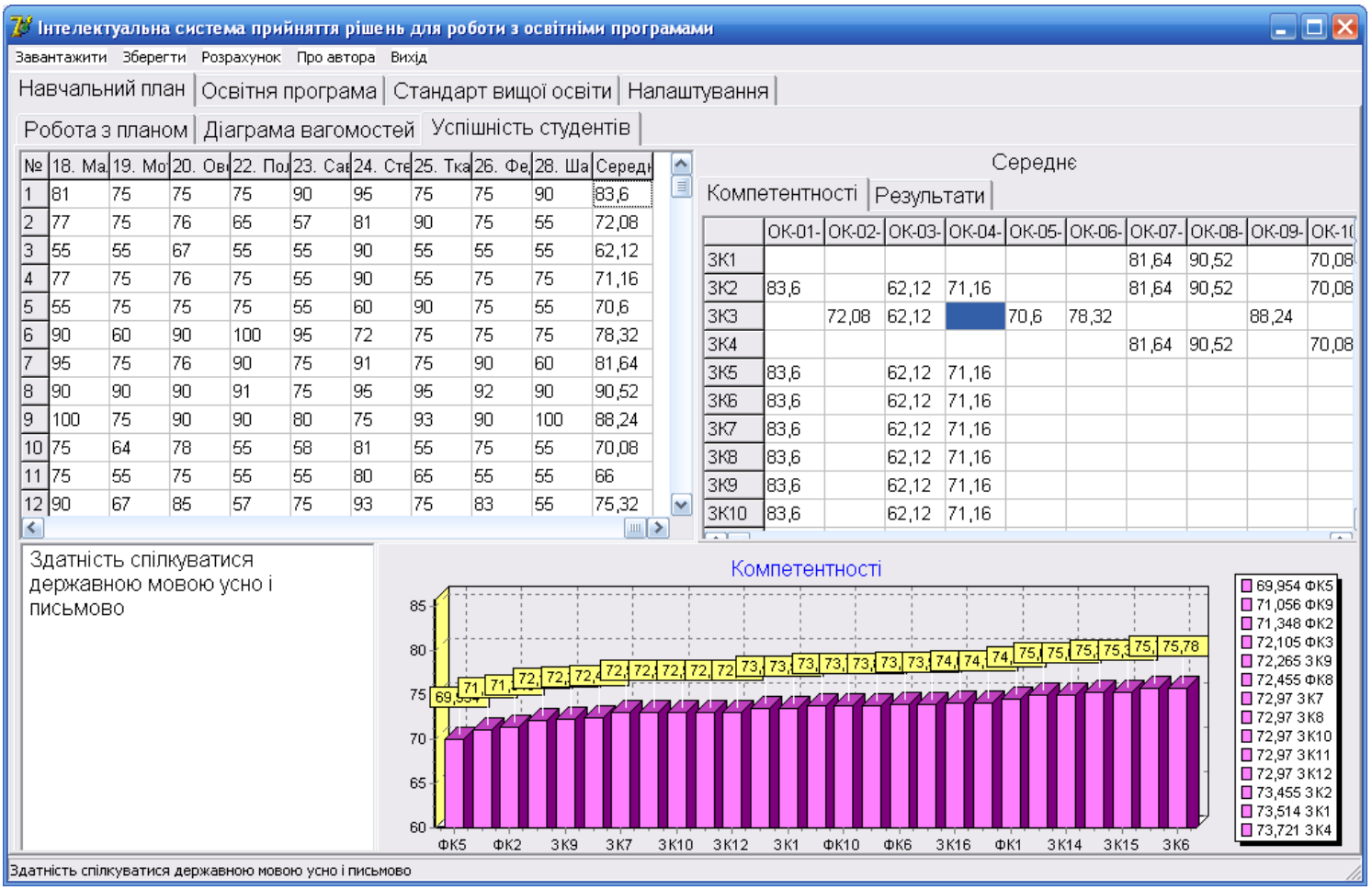

Рис. 18. Робота з успішністю групи по компетентностям 


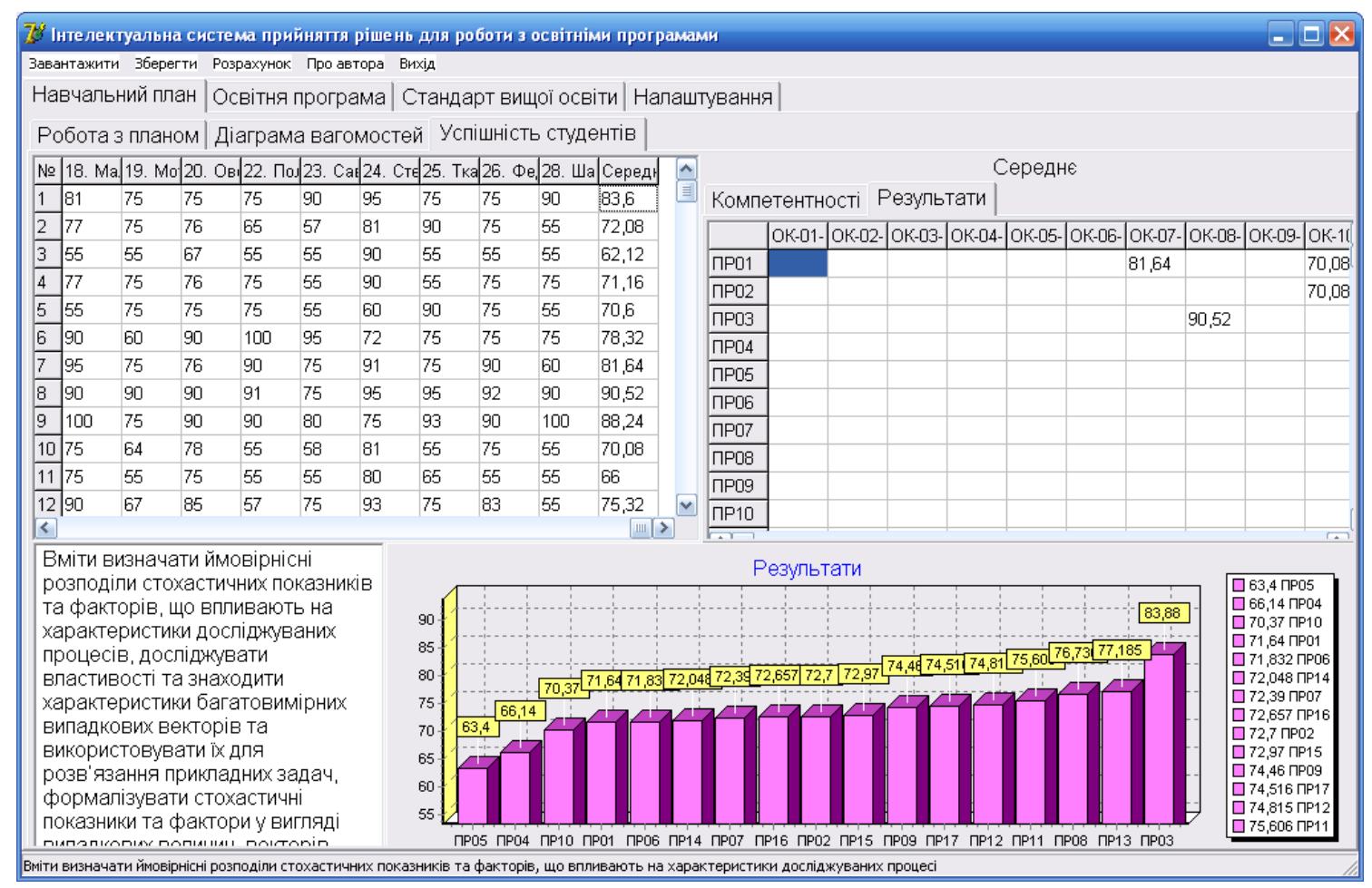

\section{Рис. 19. Робота з успішністю групи по програмним результатам навчання}

\section{3. ВИСНОВКИ ТА ПЕРСПЕКТИВИ ПОДАЛЬШИХ ДОСЛІДЖЕНЬ}

Створено інформаційну систему, яка дозволяє комплексно вирішити завдання автоматизації процесу створення освітніх програм на основі освітніх стандартів та обробки результатів навчання студентів з урахуванням компетентнісного підходу, працює зі списком компетентностей, які потрібно сформувати. та програмних результатів навчання з урахуванням виконання студентами навчального плану. Можна провести аналіз успішності студента або цілої групи в межах компетентностей або програмних результатів навчання, які вони засвоїли. Використання розробленої системи полегшить роботу 3 документами навчального виду на кафедрах при підготовці матеріалів до ліцензування й акредитації.

Перспективу подальших досліджень можна вбачати в наповненні бази даних реальними даними з дисциплін вибору студента, введенні порівняння освітніх програм різних спеціальностей одного закладу вищої освіти та однієї спеціальності різних закладів вищої освіти, а також створенні цілісної моделі оцінки якості ОПП 3 урахуванням відповідності СВО та результатам успішності.

\section{СПИСОК ВИКОРИСТАНИХ ДЖЕРЕЛ}

[1] Галузевий стандарт вищої освіти України з напряму підготовки 6.050101 «Комп’ютерні науки»: Збірник нормативних документів вищої освіти, К.: Видавнича група BHV, 2011, 85 с.

[2] Наказ Міністерства освіти і науки України від 1.06.2016p. № 600 «Методичні рекомендації щодо розроблення стандартів вищої освіти», [Електронний ресурс]. Доступно: http://search.ligazakon.ua/__doc2.nsf/link1/MUS23764.html. Дата звернення: 10.05.2019p.

[3] Затверджені стандарти вищої освіти, [Електронний ресурс]. Доступно: https://mon.gov.ua/ua/osvita/visha-osvita/naukovo-metodichna-rada-ministerstva-osviti-i-naukiukrayini/zatverdzheni-standarti-vishoyi-osviti. Дата звернення: 10.02.2019p. 
[4] Лист Міністерства освіти і науки України від 28.04.2017p. № 1/9-239 «Щодо структури ОПП», [Електронний ресурс]. Доступно: https://mon.gov.ua/storage/app/media/vishcha-osvita/rekomendatsii1648.pdf. Дата звернення: 10.05.2019p.

[5] Закон України «Про вищу освіту», [Електронний ресурс]. Доступно: https://zakon.rada.gov.ua/laws/show/1556-18. Дата звернення: 10.05.2019p.

[6] В. П. Головенкін, Освітні програми НТУУ «КПІ»: Рекомендаџії до розроблення, К.: НТУУ «КПІ», 2016, 40 c.

[7] Вступне слово до Проекту TUNING - гармонізація освітніх структур в Європі. Внесок університетів у Болонський процес, [Електронний ресурс]. Доступно: http://www.unideusto.org/tuningeu/images/stories/documents/General_Brochure_Ukrainian_version.pdf Дата звернення: 10.11.2019p.

[8] Bundesministerium fuer Bildung und Forschung - ВMBF, [Електронний ресурс]. Доступно: https://www.bmbf.de. Дата звернення: 4.12.2019p.

[9] Accueil - Ministère de l'Éducation nationale et de la Jeunesse, [Електронний ресурс]. Доступно: https://www.education.gouv.fr. Дата звернення: 4.12.2019p.

[10] European e-Competence Framework version 3.0. [Електронний ресурс]. Доступно: http://www.ecompetences.eu. Дата звернення: 4.12.2019p.

[11] Захарова Ирина Владимировна, and Кузенков Олег Анатольевич. "Опыт актуализации образовательных стандартов высшего образования в области ИКТ". Современные информационные технологии и ИТ-образование, 2017, vol. 13, no. 4, p. 46-57.

[12] Репринцева Елена Васильевна. "Анализ соответствия учебного процесса требованиям образовательных стандартов". Карельский научный журнал, 2017, vol. 6, no. 4 (21), p. 68-71.

[13] Alexander Bedny, Liliya Erushkina, and Oleg Kuzenkov, "Modernising educational programmes in ICT based on the Tuning methodology", Tuning Journal for Higher Education, Bilbao, 2014, Vol. 1, no. 2, p. 387-404.

[14] Н.А. Наумова, и Л.К. Попова, "Индикативная методика оценки качества образования", Вестник Ростовского государственного экономического университета, РИНХ, 2010, №1 (30), с.260-269.

[15] Катаев Михаил Юрьевич, Кориков Анатолий Михайлович, и Мкртчян Вардан Суренович. "Концепция и структура автоматизированной системы мониторинга качества обучения студентов" Образование и наука, 2017, vol. 19, no. 10, p. 30-46.

[16] А. Ю. Мельников, Е.В. Антонова, та С.А. Чигирь, "Разработка автоматизированной системы для ведения образовательно-профессиональных программ и образовательно-квалификационных характеристик", Актуальные вопросы современной техники и технологии: Сборник докладов II-й Международной научной заочной конференции, Липецк: Издательский центр «Де-факто», 2010, с. $50-51$.

[17] А. Ю. Мельников, та Е.В. Антонова, "Проектирование системы для работы с отраслевыми образовательными стандартами", Комп'ютерно-інтегровані технологї: освіта, наука, виробництво, Луцьк, 2011, №5, с.178-183.

[18] А. Ю. Мельников, Е.В. Антонова, та С.А. Чигирь, "Программная система для работы с отраслевыми образовательными стандартами", Вісн. Східноукр. наи. ун-ту ім. В. Даля, Луганськ, 2011, №7 (161), Ч.1, c.219-225.

[19] А. Ю. Мельников, Объектно-ориентированный анализ и проектирование информационных систем: учебное пособие, изд. 2-е, перераб. и доп., Краматорск: ДГМА, 2013, 172 с.

[20] А. Ю. Мельников, "Прогнозирование изменения вклада преподавателя в работу кафедры и использованием методов интеллектуального анализа данных", Информационные технологии $и$ средства обучения, 2018, № 1 (63), с. 266-287.[Електронний ресурс]. Доступно: http://journal.iitta.gov.ua/index.php/itlt/article/view/1949

[21] А. Ю. Мельников, Е. С. Дидевич, А. Р. Кузнецова, "Автоматизация обработки списка формируемых компетенций в стандартах высшего образования", Сучасна освіта та інтеграційні процеси: збірник наукових праць міжнародної науково-методичної конференції, 22-23 листопада 2017 року, м. Краматорськ / Під заг. ред. С. В. Ковалевського, д-ра техн. наук., проф., Краматорськ : ДДМА, 2017, с.127-128.

[22] А.Ю. Мельников, Е. С. Дидевич, "Разработка приложения для работы со списком формируемых компетенций по программным результатам обучения в стандартах высшего образования", Автоматизація та комп'ютерно-інтегровані технології у виробництві та освіті: стан, досягнення, перспективи розвитку: матеріали Всеукраӥнської науково-практичної Internetконферениіï. Черкаси, 2018, с. 148-150. 


\title{
АВТОМАТИЗИРОВАННАЯ ИНФОРМАЦИОННАЯ СИСТЕМА ОБРАБОТКИ СТАНДАРТОВ И РАЗРАБОТКИ ОБРАЗОВАТЕЛЬНЫХ ПРОГРАММ ДЛЯ ВЫСШИХ УЧЕБНЫХ ЗАВЕДЕНИЙ
}

\author{
Мельников Александр Юрьевич \\ кандидат технических наук, доцент, доцент кафедры интеллектуальных систем принятия решений \\ Донбасская государственная машиностроительная академия, г. Краматорск, Украина \\ ORCID ID 0000-0003-2701-8051 \\ alexandr@melnikov.in.ua
}

\begin{abstract}
Аннотация. В статье рассмотрены основные понятия компетентности, связанные со стандартами высшего образования и образовательно-профессиональными программами, программные результаты обучения. Проведен анализ и сделан вывод, что в настоящее время нет компьютерной системы, позволяющей комплексно решать задачи автоматизации процесса обработки образовательных стандартов и образовательных программ. Сформулирована задача создания программной системы, которая позволяла бы работать со списком формируемых компетенций по предметам и программным результатам обучения. Приведена объектно ориентированная модель проектируемой компьютерной системы на языке визуального моделирования UML в виде диаграммы вариантов использования и диаграммы классов. Обоснован выбор формата исходных данных, который позволял бы вносить изменения в данные без использования приложения, а также не предъявлять дополнительные требования к установке программного обеспечения. Приведено описание компьютерной реализации программной системы, осуществленной в среде визуального программирования Object-Pascal, и пример работы системы на основании реальных данных - стандарта подготовки бакалавра по специальности 124 «Системный анализ» и образовательно-профессиональной программы «Интеллектуальные системы принятия решений». Показано, что работа со стандартом высшего образования позволяет просмотреть общие компетентности, специальные компетентности и программные результаты обучения в виде матрицы соответствия. Работа с образовательной программой, кроме этого, позволяет создавать и корректировать матрицу соответствия компетентностей компонентам и матрицу обеспечения программных результатов обучения компонентами. Работа с учебным планом предполагает установку соответствия каждой дисциплины программным результатам по итогам ее изучения, расчет объема кредитов ECTS на каждую компетенцию или программный результат обучения, а также анализ успеваемости студента или целой группы в терминах компетенций или программных результатов обучения, которые они освоили.
\end{abstract}

Ключевые слова: стандарт высшего образования; образовательно-профессиональная программа; компетенции; программные результаты обучения; предметы; информационная система; Unified Modeling Language; Object-Pascal.

\section{AUTOMATED INFORMATION SYSTEM FOR PROCESSING STANDARDS AND DEVELOPING EDUCATIONAL PROGRAMS FOR HIGHER EDUCATIONAL INSTITUTIONS}

\author{
Oleksandr Y. Melnykov \\ PhD of Technical Sciences, Associate Professor at the Department of Intelligent Decision Making Systems \\ Donbass State Engineering Academy, Kramatorsk, Ukraine \\ ORCID ID 0000-0003-2701-8051 \\ alexandr@melnikov.in.ua
}

\begin{abstract}
The basic concepts related to the standards of higher education and educational and professional programs - competence, program learning outcomes are considered. The analysis was carried out and the conclusion was drawn that at present there is no computer system allowing to solve complex problems for automating the processing of educational standards and educational programs. The task of creating a software system that would allow working with a list of formed competences on subjects and program learning outcomes is formulated. An object-
\end{abstract}


oriented model of a designed computer system is presented in the language of visual modeling UML in the form of a use case diagram and class diagram. The choice of the source data format, which would allow making changes to the data without using the application, and does not impose additional requirements for installing software, is justified. A description of the computer implementation of the software system implemented in the Object-Pascal visual programming environment is given, as well as an example of the system's operation based on real data - the standard of bachelor's training in the specialty 124 "System Analysis" and the educational and professional program "Intelligent Decision Making Systems". It is shown that working with the standard of higher education allows you to view general competences, special competences and program learning outcomes in the form of a compliance matrix. Work with the educational program in addition allows you to create and adjust the matrix of correspondence of the competences to the components and the matrix of ensuring the program learning outcomes with the components. Working with the curriculum involves setting the correspondence of each discipline to program results based on its study, calculating the amount of ECTS credits for each competency or program result of training, as well as analyzing the progress of a student or an entire group in terms of the competences or program results of learning that they have mastered.

Keywords: higher education standard; educational and professional program; competences; program learning outcomes; subjects; information system; Unified Modeling Language; ObjectPascal.

\section{REFERENCES (TRANSLATED AND TRANSLITERATED)}

[1] Industry standard of higher education of Ukraine in the direction of training 6.050101 "Computer Science": Collection of normative documents of higher education (2011). K: BHV, 85. (in Ukrainian)

[2] Order of the Ministry of Education and Science of Ukraine dated June 1, 2016 № 600 "Guidelines for the development of standards of higher education". [Online]. Available: http://search.ligazakon.ua/1_doc2.nsf/link1/MUS23764.html. (in Ukrainian)

[3] Approved standards of higher education. [Online]. Available: https://mon.gov.ua/ua/osvita/vishaosvita/naukovo-metodichna-rada-ministerstva-osviti-i-nauki-ukrayini/zatverdzheni-standarti-vishoyiosviti. (in Ukrainian)

[4] Letter from the Ministry of Education and Science of Ukraine dated April 28, 2017 № 1 / 9-239 "Regarding the structure of the OPP". [Online]. Available: https://mon.gov.ua/storage/app/media/vishchaosvita/rekomendatsii-1648.pdf. (in Ukrainian)

[5] Law of Ukraine "On Higher Education". [Online]. Available: https://zakon.rada.gov.ua/laws/show/155618. (in Ukrainian)

[6] V. P. Holovenkin, (2016). Educational programs of NTUU "KPI": Recommendations for development. $\mathrm{K} .: \mathrm{NTUU} \ll \mathrm{KPI}$, 40. (in Ukrainian)

[7] Introductory word to the TUNING Project - harmonization of educational structures in Europe. The contribution of universities to the Bologna Process. [Online]. Available: http://www.unideusto.org/tuningeu/images/stories/documents/General_Brochure_Ukrainian_version.pdf (in Ukrainian)

[8] Bundesministerium fuer Bildung und Forschung. [Online]. Available: https://www.bmbf.de. (in German)

[9] Accueil - Ministère de l'Éducation nationale et de la Jeunesse. [Online]. Available: https://www.education.gouv.fr. (in French)

[10] European e-Competence Framework version 3.0. [Online]. Available: http://www.ecompetences.eu. (in English)

[11] I. V. Zaharova, O. A. Kuzenkov, (2017). Experience in updating educational standards of higher education in the field of ICT. Sovremennye informacionnye tehnologii i IT-obrazovanie. vol. 13, no. 4, pp.46-57. (in Russian)

[12] E.V. Reprinceva, (2017). Analysis of the compliance of the educational process with the requirements of educational standards. Karel'skij nauchnyj zhurnal, vol. 6, no. 4 (21), pp.68-71. (in Russian)

[13] A. Bedny, L. Erushkina, O. Kuzenkov, (2014). Modernizing educational programmes in ICT based on the Tuning methodology. Tuning Journal for Higher Education, Bilbao, vol. 1, no. 2, pp.387-404. (in English)

[14] N.A. Naumova, L. K. Popova, (2010). Indicative methodology for assessing the quality of education. Vestnik Rostovskogo gosudarstvennogo jekonomicheskogo universiteta, RINH, no. 1 (30), pp.260-269. (in Russian) 
[15] M. Ju. Kataev, A. M. Korikov, V. S. Mkrtchjan, (2017). Concept and structure of an automated system for monitoring the quality of student learning. Obrazovanie $i$ nauka, vol. 19, no. 10, pp.30-46. (in Russian)

[16] A. Yu. Mel'nikov, E. V. Antonova, S. A. Chigir', (2010). Development of an automated system for conducting educational and professional programs and educational and qualification characteristics. Topical issues of modern technology and technology: Collection of reports of the II International Scientific Correspondence Conference, Lipeck: Izdatel'skij centr «De-fakto», 50-51. (in Russian)

[17] A. Yu. Mel'nikov, E. V. Antonova, (2011). Designing a system to work with industry educational standards, Kompiuterno-intehrovani tekhnolohii: osvita, nauka, vyrobnytstvo, Lutsk, no. 5, pp.178-183. (in Russian)

[18] O. Yu. Mel'nikov, E.V. Antonova, S. A. Chigir', (2011). A software system for working with industry educational standards. Visn. Skhidnoukr. nats. un-tu im. V. Dalia, Luhansk, no. 7(161), vol. 1, pp.219225. (in Russian)

[19] O. Yu. Melnikov, (2013). Object-oriented analysis and design of information systems: a tutorial, ed. 2nd, rev. and additional. Kramatorsk, DGMA, 172. (in Russian)

[20] O. Yu. Melnykov, (2018). Forecasting the change in the teacher's contribution to the work of the department using the methods of data mining. Information Technologies and Learning Tools, No. 1 (63), pp.266-287. (in Russian)

[21] A. Yu. Melnikov, E. S. Didevich, A. R. Kuznecova, (2017). Automation of processing a list of formed competencies in higher education standards. Modern education and integration processes: a collection of scientific papers of the international scientific-methodical conference, November 22-23, 2017, Kramatorsk Under the general. ed. SV Kovalevsky, Dr. Tech. Science, Prof., 127-128. (in Russian)

[22] A. Yu. Melnikov, E. S. Didevich, (2018). Development of an application for working with a list of formed competencies based on program learning outcomes in higher education standards. Automation and computer-integrated technologies in production and education: state, achievements, development prospects: materials of the All-Ukrainian scientific-practical Internet-conference, Cherkasy, pp.148-150. (in Russian)

\section{(cc) EY-NC-SA}

This work is licensed under Creative Commons Attribution-NonCommercial-ShareAlike 4.0 International License. 